\title{
O PERFIL DO PROFESSOR \\ NAS ETAPAS DA EDUCAÇÃO BÁSICA*
}

\author{
Maria Regina Viveiros de Carvalho ${ }^{\mathrm{I}}$
}

http://dx.doi.org/10.24109/9788578630669.ceppe.vla4

\section{RESUMO}

Este estudo analisa o perfil dos professores nas diferentes etapas de ensino da educação básica. Foram utilizados dados do Censo da Educação Básica dos anos de 2009 e 2017, analisando-se o perfil demográfico, a formação do professor e o contexto de trabalho. Os resultados mostraram que, em todas as etapas, a maioria dos docentes é do sexo feminino e de raça/cor branca, está na faixa etária entre 39 e 42 anos, tem formação em nível superior e está distribuída prioritariamente em escolas do Sudeste e do Nordeste. Existem, no entanto, algumas peculiaridades por etapas: i) professores das etapas iniciais são mais jovens; ii) há maior participação de professores com formações de nível médio na educação infantil e nos anos iniciais quando comparados aos anos finais e ao ensino médio; iii) nas etapas iniciais, professores estão mais alocados em escolas municipais; nas etapas finais, existe participação maior em escolas estaduais; iv) nos anos finais e no ensino médio, os professores possuem vínculos com maior quantidade de turmas, escolas e disciplinas.

Palavras-chave: perfil dos professores; educação básica; etapas da educação.

* Informações mais abrangentes sobre o perfil do professor podem ser encontradas no estudo "O perfil do professor da educação básica”, publicado pelo Instituto Nacional de Estudos e Pesquisas Educacionais Anísio Teixeira (Inep), Relatos de Pesquisa $n^{\circ} 41$.

I Maria Regina Viveiros de Carvalho é mestre em administração pública pela Universidade de Brasília (UnB) e pesquisadora do Instituto Nacional de Estudos e Pesquisas Educacionais Anísio Teixeira (Inep), atuando na Diretoria de Estudos Educacionais (Dired). 


\section{INTRODUÇÃO}

De acordo com a Lei de Diretrizes e Bases da Educação (LDB), a educação básica “[...] tem por finalidade desenvolver o educando, assegurar-lhe a formação comum indispensável para o exercício da cidadania e fornecer-lhe meios para progredir no trabalho e em estudos posteriores" (Brasil, 1996, art. 22). A LDB estipula em seu artigo $4^{\circ}$ que a educação básica brasileira se segmenta nas seguintes etapas de ensino: i) educação infantil - crianças de até 6 anos de idade; ii) ensino fundamental - de 6 a 14 anos; e iii) ensino médio - de 15 a 17 anos (Brasil, 1996). Segundo ilustra Cury (2008, p. 295), “[...] a educação infantil é a raiz da educação básica, o ensino fundamental é o seu tronco e o ensino médio é seu acabamento”.

Essa forma de organização reflete objetivos educacionais que dizem respeito a condições específicas do desenvolvimento do aluno (Cury, 2002), conforme as fases de sua vida (que afetam a forma com que ele lida com o aprendizado), e podem impor ao docente algumas exigências. Para cada etapa, o professor deve conhecer e sistematizar os conteúdos a serem apresentados, adaptados pela compreensão da realidade social e cultural dos alunos, das características de cada faixa etária e das histórias pessoais e individualidades de cada um (Oliveira; Alves, 2005). Assim, a etapa de ensino em que o professor leciona propõe a ele alguns percursos profissionais que podem se refletir em peculiaridades de seu perfil.

O objetivo deste trabalho é analisar o perfil dos professores, caracterizados por etapas de ensino da educação básica, buscando evidências de eventuais especificidades, gerando subsídios à compreensão da inter-relação entre as características desses profissionais e as políticas públicas relacionadas às etapas da educação. Como afirmam Souza e Gouveia (2011, p. 2), conhecer as características dos professores é importante, pois embora

\footnotetext{
não [sejam] constituídos pela política educacional, [...] tem nela interferência, seja pelas intervenções que o policy maker pode ou não fazer, considerando quem são os docentes; seja pela conquista de direitos por esses profissionais; seja ainda pela relação mais direta, decorrente do fato que são os docentes, no limite, os garantidores (ou não) de que qualquer política educacional chegue efetivamente até as salas de aula e demais espaços educativos.
}

A principal diferença a ser analisada no perfil do docente para cada etapa de ensino diz respeito ao tipo de formação e ao nível de escolaridade esperado para os professores que nela atuam, "[...] de modo a atender aos objetivos dos diferentes níveis e modalidades de ensino e às características de cada fase do desenvolvimento do educando" (Brasil, 1996, art. 61).

O Decreto $\mathrm{n}^{\circ} 3.276 / 99$ estabelece dois tipos de formação para o professor conforme a etapa de ensino: i) uma para atuação multidisciplinar, destinada ao magistério na educação infantil e anos iniciais; e ii) outra, em campos específicos 
de conhecimento, para atuar no ensino de sua especialidade. Nesse último caso, o Parecer $n^{0}$ 02/2008 do Conselho Nacional de Educação (CNE) afirma que "[...] os docentes oriundos das licenciaturas específicas devem atuar nos campos específicos curriculares, desta forma organizados nas séries finais do ensino fundamental e do ensino médio" (Brasil. CNE, 2008, p. 8).

Tanto a LDB quanto o Plano Nacional de Educação (PNE) indicam a necessidade de formação em nível superior para lecionar na educação básica. No entanto, a LDB admite a formação em nível médio na modalidade normal para atuar na educação infantil e nos anos iniciais e exige formação de nível superior para os anos finais e o ensino médio. A meta 15 do PNE destaca que essa formação deve ser compatível com a disciplina que o professor leciona. Essas diferenciações podem produzir efeitos sobre algumas características do perfil dos professores de cada etapa.

A análise teve como base os dados do Censo da Educação Básica de 2009 e de 2017, especialmente o cadastro de profissionais da educação, com foco nos professores em regência de classe, mediante os quais se descreveram características do docente (demográficas, de formação e do contexto de trabalho). Nas próximas seções, serão apresentadas características das etapas da educação básica e, em seguida, as análises do perfil dos professores que lecionam nessas etapas.

\section{A DOCÊNCIA NAS ETAPAS DA EDUCAÇÃO BÁSICA}

\subsection{EDUCAÇÃO INFANTIL}

A educação infantil é a primeira etapa da educação básica, atendendo crianças de até 3 anos (creche) e de 4 a 6 anos (pré-escola), e é considerada parte integrante do percurso educativo, articulando-se com as demais etapas de ensino - entendimento diferente do foco que se tinha no passado, de que nessa fase a atuação da escola era somente assistencialista (Cury, 2002). Espera-se que as crianças, nessa etapa, desenvolvam capacidades que fundamentem o seu desenvolvimento futuro (nos aspectos físicos, emocionais, cognitivos e sociais).

O professor da educação infantil precisa ser capaz de compreender os processos de aprendizado e desenvolvimento nessa faixa etária e as necessidades das crianças, interagindo e apresentando intervenções didáticas e oportunidades de experiências, de forma a conduzi-las no processo de construção do conhecimento e de seu desenvolvimento integral (Cury, 2002). Nessa fase, a criança é ainda muito dependente e vulnerável, sendo o professor responsável não só por exercer seu papel de educador, mas também por cuidar do bem-estar do aluno.

A exigência legal para o exercício da docência na educação infantil estabelece que os professores tenham formação em nível superior, admitindo-se, no entanto, formação em nível médio na modalidade normal (Brasil, 1996). 


\subsection{ENSINO FUNDAMENTAL}

O ensino fundamental é a etapa que segue à educação infantil, atendendo crianças de 6 a 14 anos; organiza-se em nove anos - anos iniciais (do $1^{\circ}$ ao $5^{\circ}$ ano) e anos finais (do $6^{\circ}$ ao $9^{\circ}$ ano); e tem por objetivo "a formação básica do cidadão" (Brasil, 1996, art. 32). Isso inclui desenvolver na criança capacidade de argumentação e espírito crítico para lidar com as situações cotidianas, integrando o conhecimento e amadurecendo o estudante de forma progressiva, de acordo com os níveis de desenvolvimento desse período de vida (Brasil. MEC, 2017). O professor deve ser capaz de organizar e orientar as situações de aprendizagem e acompanhar o progresso dos alunos, envolvendo-os em seu próprio processo evolutivo.

Professores que lecionam nos anos iniciais do ensino fundamental em geral são responsáveis pela turma o ano inteiro, atuando majoritariamente de forma multidisciplinar. Embora haja recomendação legal para que tenham formação em nível superior, admite-se para a docência nos anos iniciais a formação em nível médio normal (Brasil, 1996). Os professores dos anos finais do ensino fundamental são organizados por disciplinas, com a possibilidade de atuarem em diferentes turmas ao longo do ano escolar. Para lecionar nesses anos, exige-se a formação em nível superior, adequada à disciplina ministrada.

\subsection{ENSINO MÉDIO}

O ensino médio corresponde à ultima etapa da educação básica, em sequência ao ensino fundamental, na qual se aprofunda e consolida o conhecimento obtido ao longo de todo o percurso escolar, permitindo o prosseguimento dos estudos e a capacitação para o mercado de trabalho e para o exercício da cidadania (Brasil, 1996). Os professores dessa etapa são organizados conforme disciplinas específicas e precisam ter formação em nível superior em área compatível com essas disciplinas.

No ensino médio, o professor vai lidar com um perfil diferente de alunos, que estão em fase de transição, em busca de orientação e preparo para a vida profissional e para a cidadania. Nessa fase de vida, o jovem pode já estar buscando colocação precoce no mercado de trabalho ou trazer defasagem em seu aprendizado, dificultando a continuidade de seus estudos - esses fatores podem levar, nessa etapa de ensino, à evasão escolar (Mendes, 2013). É uma situação que exige do professor experiência e capacidade para desenvolver estratégias de ensino contemporâneas, que atraiam o aluno e que vão além do conteúdo escolar - é preciso envolver e engajar os estudantes em um processo interessante de aprendizagem, como forma de reduzir essa evasão. 


\subsection{PERFIL DO PROFESSOR}

O Gráfico 1 apresenta a distribuição dos professores da educação básica nos anos de 2009 e 2017.

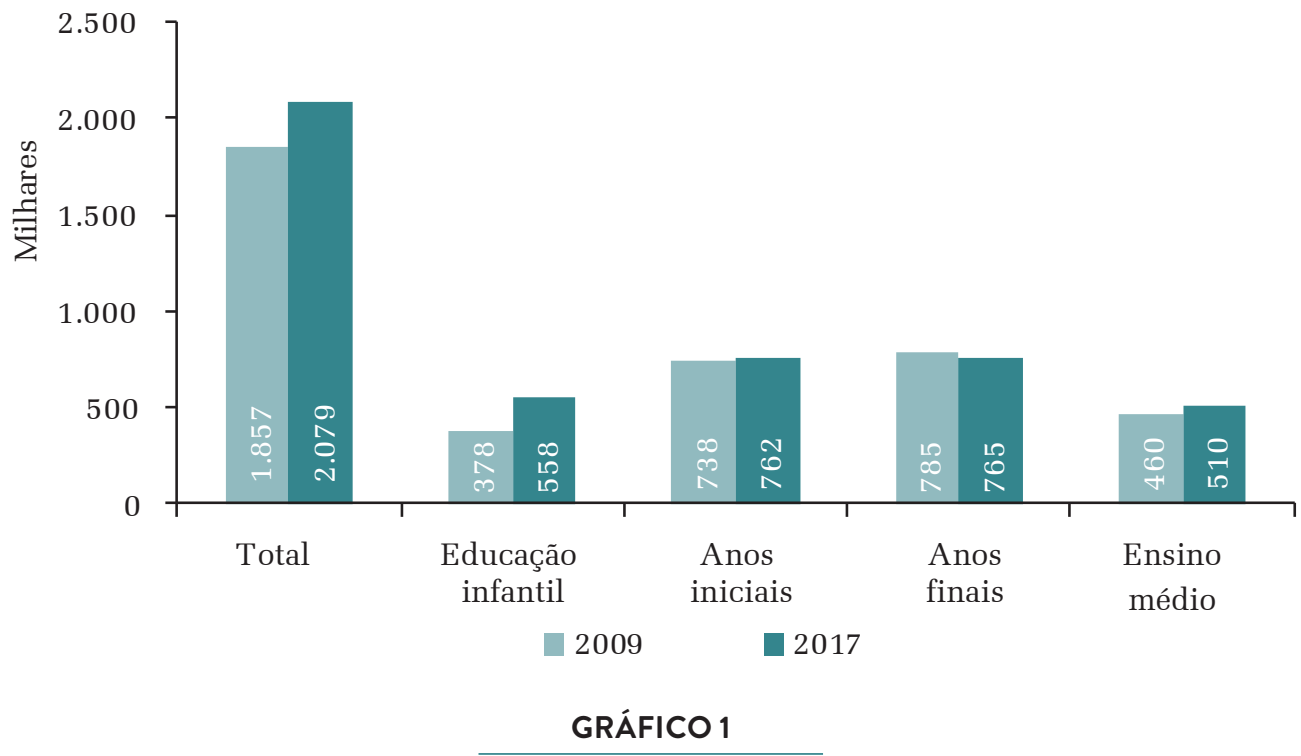

EVOLUÇÃO DA QUANTIDADE DE PROFESSORES DA EDUCAÇÃO BÁSICA, POR ETAPAS DE ENSINO - BRASIL - 2009/2017

Fonte: Elaboração própria com base em dados do Censo da Educação Básica.

O número de professores da educação infantil no Brasil é menor do que o de professores do ensino fundamental, mas apresenta ritmo de crescimento maior, ou seja, ao longo do período estudado, mais professores ingressaram no sistema de ensino para lecionar na educação infantil do que nas demais etapas. Isso pode ser explicado pelo fato de que, se para essa etapa a exigência de nível de formação é menor, ela seria a porta de entrada no sistema educacional para professores ainda sem formação superior, o que é admitido como adequado à educação infantil (Gatti; Barretto, 2009). Outra explicação possível é a de que houve crescimento considerável da oferta dessa etapa de ensino no período, demandando maior número de professores - e, portanto, mais ingressantes.

O ensino fundamental conta com a maior quantidade de professores em relação às demais etapas, mas a tendência histórica mostra que essa quantidade não tem crescido de forma evidente, mantendo-se relativamente estável ao longo dos anos, tanto para os anos iniciais quanto para os anos finais. Professores do ensino médio estão em número menor do que os do ensino fundamental, e houve um crescimento ligeiramente positivo ao longo do período. 
A distribuição dos professores de cada etapa, desagregados por região geográfica, está retratada no Gráfico 2.

Educação Infantil

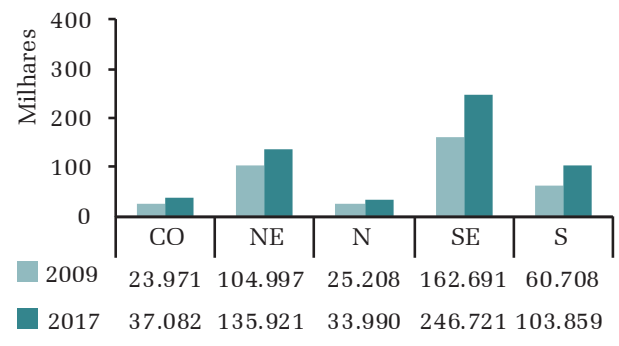

Anos Finais

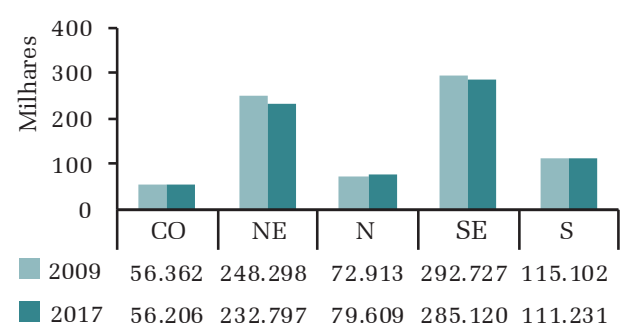

Anos iniciais

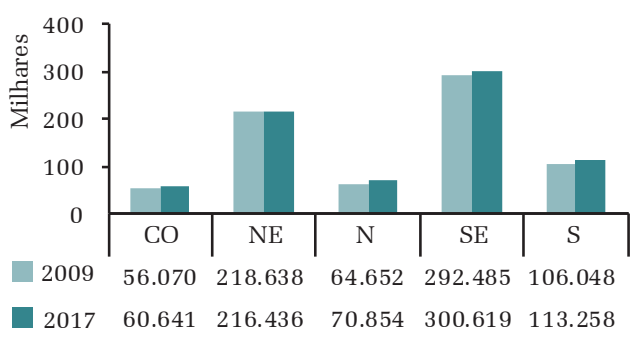

$\begin{array}{llllll}2009 & 35.328 & 118.281 & 29.836 & 203.375 & 73.435\end{array}$

— $2017 \quad 39.838 \quad 126.487 \quad 37.706 \quad 226.647 \quad 79.438$

GRÁFICO 2

\section{QUANTIDADE DE PROFESSORES DA EDUCAÇÃO BÁSICA, POR ETAPAS DE ENSINO E REGIÃO GEOGRÁFICA - BRASIL - 2009/2017}

Fonte: Elaboração própria com base em dados do Censo da Educação Básica.

Ao se analisar o Gráfico 2, observa-se, na educação infantil, uma taxa de crescimento no número de professores bem evidente, principalmente nas regiões Sudeste e Sul. No ensino fundamental, a quantidade de professores mostra tendência à estabilidade ao longo dos anos, com distribuição regional bastante semelhante entre os anos iniciais e os finais. Nos anos finais, percebe-se, no Nordeste, no Sudeste e no Sul, ligeira variação negativa do número de professores.

A tendência de estabilidade ou de decréscimo da quantidade de docentes no ensino fundamental, principalmente nos anos finais, pode ser resultado, por exemplo, do número mais estável de alunos que cursam esses anos, retrato da inversão de tendência da pirâmide populacional brasileira (que mostra queda da população nessa faixa etária, demandando menos o sistema educacional).

No ensino médio, a tendência é de ligeiro crescimento na quantidade de professores, mais evidente na região Sudeste. Interessante notar que, comparando dados das sinopses estatísticas da Educação Básica de 2009 e de 2017, percebe-se que houve diminuição na quantidade de matrículas no ensino médio, como também ocorreu no ensino fundamental (Brasil. Inep, 2010; 2018). No entanto, ao contrário do observado 
para os anos finais, apesar de menor demanda, no ensino médio a quantidade de professores cresceu.

O Gráfico 3 mostra como os professores de cada etapa se distribuem conforme a dependência administrativa da escola. Professores da educação infantil estão distribuídos prioritariamente em escolas das redes municipais, com ínfima participação em escolas federais ou estaduais. Nos anos iniciais, estão principalmente alocados em escolas municipais, com alguma participação da rede estadual. Já professores dos anos finais concentram-se em escolas estaduais ou municipais. No ensino médio, os professores estão predominantemente em escolas estaduais e quase não estão presentes em escolas federais ou municipais. A participação de docentes na rede privada é quantitativamente semelhante em todas as etapas de ensino.

Esses dados estão de acordo com o que determina a Constituição Federal, em seu artigo 211, que indica que os municípios terão atuação prioritária no ensino fundamental e na educação infantil e que os estados atuarão prioritariamente no ensino fundamental e no médio (Brasil, 1988).

Educação Infantil

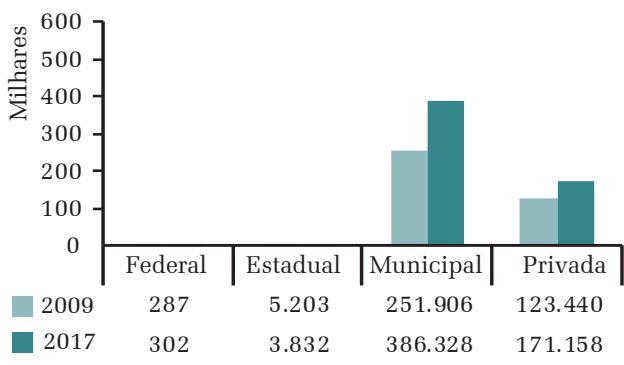

Anos Finais

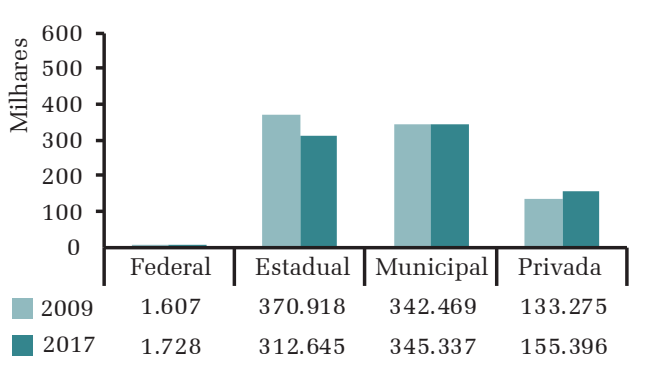

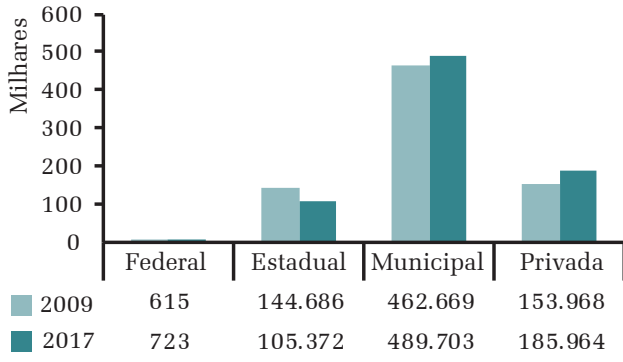

Ensino Médio

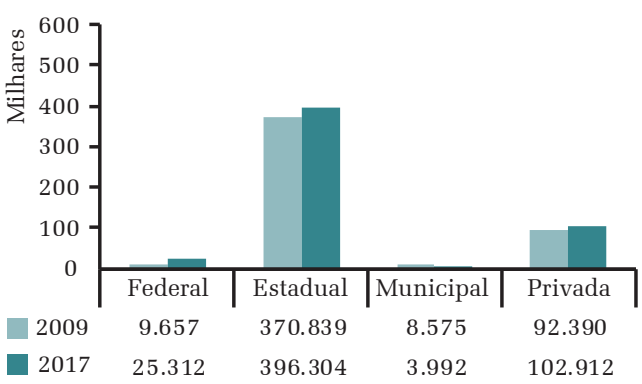

GRÁFICO 3

\section{QUANTIDADE DE PROFESSORES DA EDUCAÇÃO BÁSICA, POR ETAPAS DE ENSINO E DEPENDÊNCIA ADMINISTRATIVA - BRASIL - 2009/2017}

Fonte: Elaboração própria com base em dados do Censo da Educação Básica. 
A análise da distribuição dos professores por etapa conforme o sexo é exposta no Gráfico 4. A maioria dos docentes, em todas as etapas, é do sexo feminino. A proporção de mulheres em relação à de homens, no entanto, é muito maior na educação infantil. No ensino fundamental, predominam professoras, com uma proporção maior nos anos iniciais e um pouco menor nos anos finais. Também no ensino médio, a maioria de professores é composta por mulheres, mas, em relação às outras etapas de ensino, a participação destas em comparação à dos homens é menor, ou seja, mais professores homens lecionam no ensino médio do que em outras etapas de ensino.

Educação Infantil

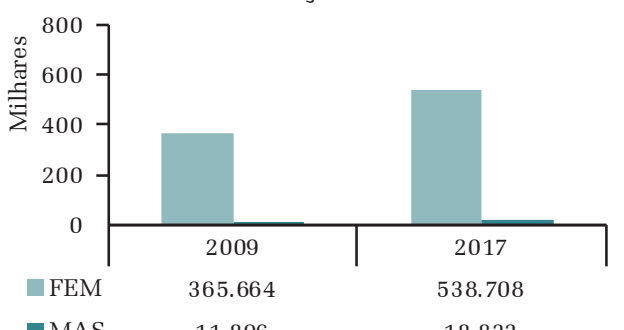

aMS $\quad 11.896$

Anos Finais

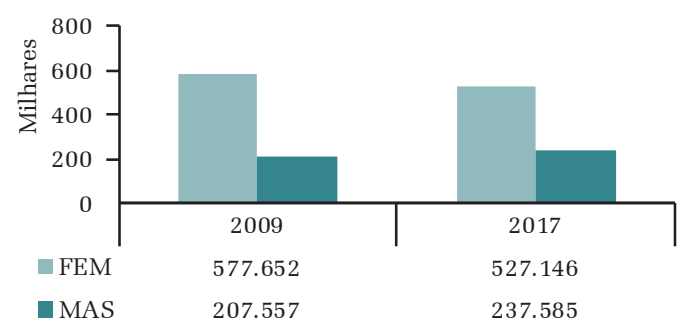

Anos Iniciais

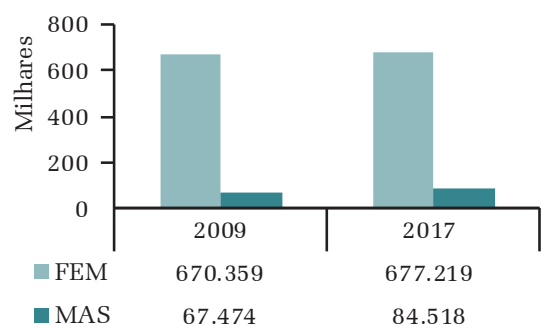

Ensino Médio

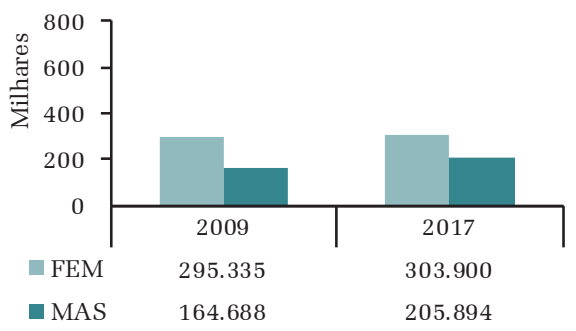

GRÁFICO 4

QUANTIDADE DE PROFESSORES DA EDUCAÇÃO BÁSICA, POR ETAPAS DE ENSINO E SEXO - BRASIL - 2009/2017

Fonte: Elaboração própria com base em dados do Censo da Educação Básica.

A evolução progressiva da presença de professores homens na educação básica mostra que a inserção deles se dá, em geral, nas etapas mais avançadas. Isso pode estar relacionado, por exemplo, à tradição histórica e cultural de alocação de mulheres como professoras, principalmente para os níveis iniciais da educação, no trato com crianças pequenas (Vianna, 2001; Gatti; Barretto, 2009), ou ao fato de que os homens possam mostrar mais interesse por lecionar nas séries mais avançadas.

A distribuição dos professores de cada etapa segundo a raça/cor declarada no Censo da Educação Básica é retratada no Gráfico 5. 
Educação Infantil

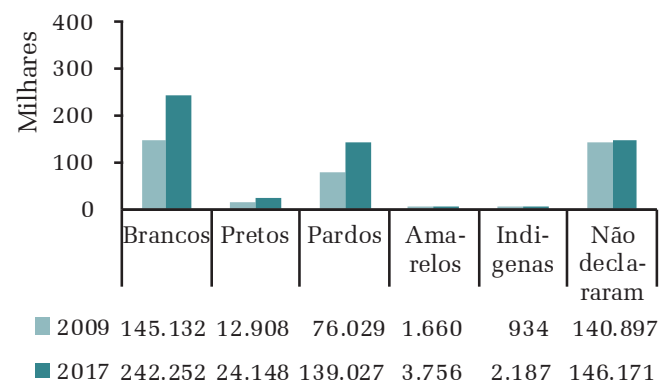

Anos Iniciais

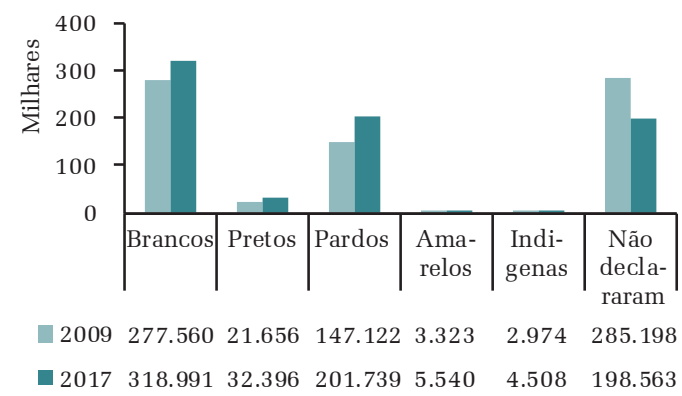

Anos Finais

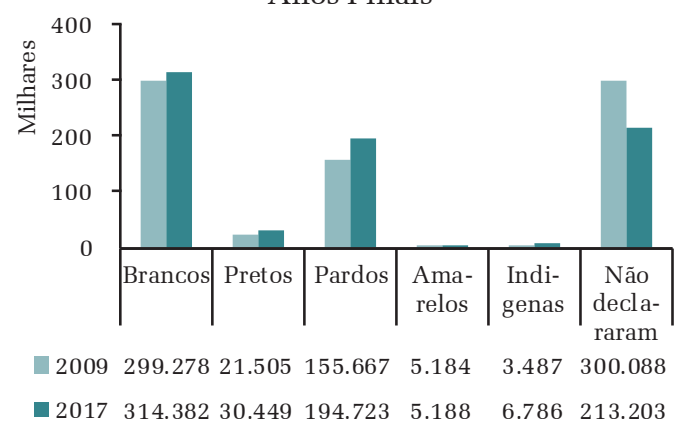

Ensino Médio

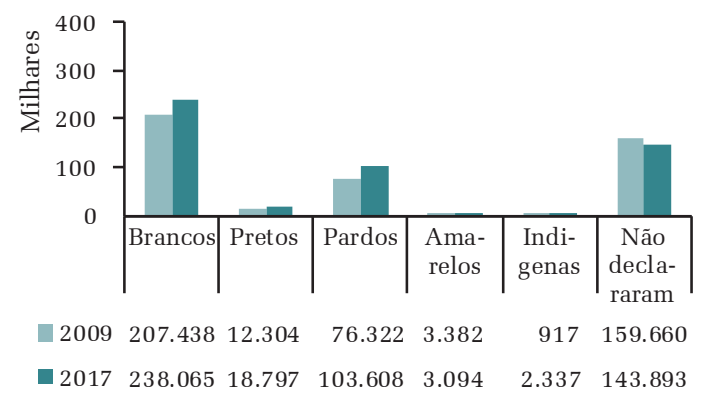

GRÁFICO 5

\section{QUANTIDADE DE PROFESSORES DA EDUCAÇÃO BÁSICA, POR ETAPAS DE ENSINO E RAÇA/COR - BRASIL - 2009/2017}

Fonte: Elaboração própria com base em dados do Censo da Educação Básica.

Em todas as etapas predominam professores que se autodeclaram brancos, seguidos pelos que se declaram pardos, em menores proporções - a diferença entre brancos e pardos se mantém relativamente estável ao longo do período. A representatividade dos demais segmentos de raça/cor é bastante menor, mas todos apresentam tendência de crescimento no período. Os dados mostram que persiste, ainda, alguma desigualdade no acesso a oportunidades de docência entre os diferentes segmentos de raça/cor. Isso pode ser reflexo, por exemplo, da desigualdade quanto ao nível educacional entre brancos e as demais categorias de raça/cor, ou seja, se brancos têm mais oportunidades de atingir a escolaridade necessária para serem professores (nível médio, no mínimo), podem estar mais bem representados nesse perfil profissional (Gatti; Barretto, 2009).

A descrição das idades dos professores, por etapa da educação, consta na Tabela 1. 
TABELA 1

DESCRIÇÃO ETÁRIA DE PROFESSORES DA EDUCAÇÃO BÁSICA, POR ETAPAS DE ENSINO - BRASIL - 2009/2017

\begin{tabular}{|l|l|c|c|c|c|}
\multirow{2}{*}{ Etapa } & \multicolumn{4}{|c}{ Idade de professor } \\
\cline { 3 - 7 } & & Média & DP & Mediana & Moda \\
\hline \multirow{2}{*}{ Ed. infantil } & $\mathbf{2 0 0 9}$ & 36,24 & 9,19 & 35 & 30 \\
\cline { 2 - 6 } & $\mathbf{2 0 1 7}$ & 39,47 & 9,55 & 39 & 36 \\
\hline \multirow{2}{*}{ Anos iniciais } & $\mathbf{2 0 0 9}$ & 36,25 & 9,45 & 38 & 32 \\
\cline { 2 - 6 } & $\mathbf{2 0 1 7}$ & 41,40 & 9,54 & 41 & 38 \\
\hline \multirow{2}{*}{ Anos finais } & $\mathbf{2 0 0 9}$ & 38,90 & 9,85 & 38 & 31 \\
\hline \multirow{2}{*}{ Ens. médio } & $\mathbf{2 0 1 7}$ & 41,19 & 9,99 & 40 & 36 \\
\hline & $\mathbf{2 0 0 9}$ & 39,82 & 9,85 & 39 & 44 \\
\hline
\end{tabular}

Fonte: Elaboração própria com base em dados do Censo da Educação Básica.

Observa-se, de forma geral, o aumento da idade média dos professores em todas as etapas de ensino. As médias etárias, apesar de serem bastante próximas, mostram que os docentes da educação infantil são um pouco mais jovens do que os de outras etapas.

Isso pode estar relacionado às distinções de perfil de formação dos professores exigido para cada etapa, ou seja, pode ser que as etapas iniciais do ensino, em que formação em nível médio é admitida, apresentem oportunidades maiores de ingresso na carreira docente para profissionais jovens, que ainda não possuem nível superior.

No ensino fundamental os professores estão em uma faixa etária, em média, maior do que a dos professores da educação infantil, mas menor do que a dos professores do ensino médio, sem que tenha havido diferenças significativas entre médias etárias de anos iniciais e anos finais. Já no ensino médio, os professores apresentaram a maior média etária entre as etapas de ensino.

Em todas as etapas predominam professores com formação em nível superior, com tendência de crescimento desse tipo de formação ao longo do tempo. A formação de nível médio é mais frequente na educação infantil e nos anos iniciais, mas a evolução observada mostra que o número de professores com essa escolaridade está diminuindo. Professores com ensino fundamental ou menos são residuais em todas as etapas, apontando também tendência de diminuição ao longo do tempo.

O Gráfico 6 traz a escolaridade do professor por etapa da educação. 
Educação Infantil

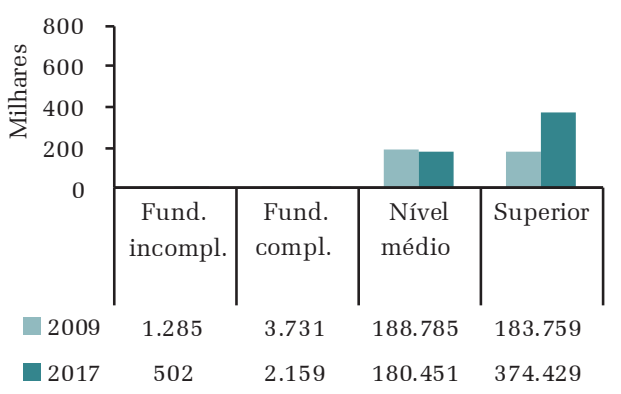

Anos Finais

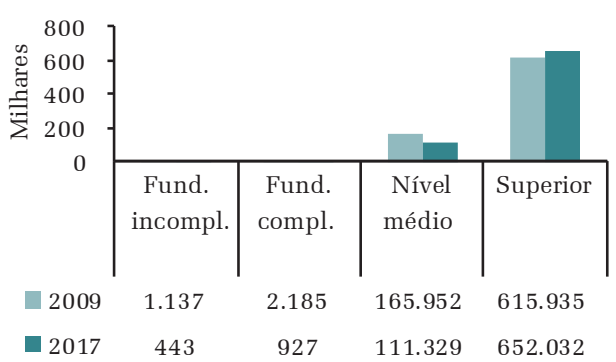

Anos Iniciais

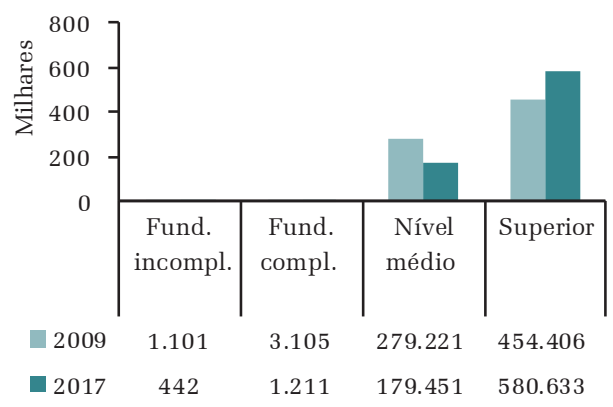

Ensino Médio

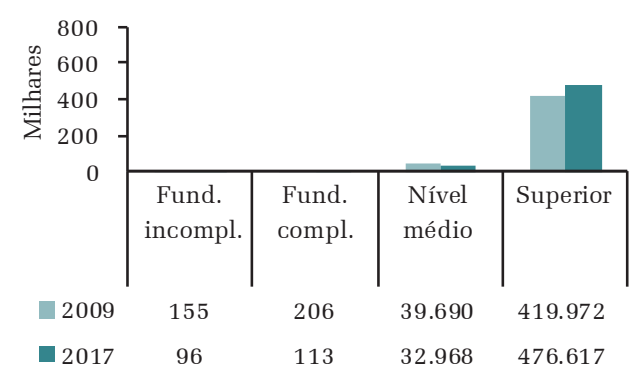

GRÁFICO 6

\section{QUANTIDADE DE PROFESSORES DA EDUCAÇÃO BÁSICA, POR ETAPAS DE ENSINO E ESCOLARIDADE - BRASIL - 2009/2017}

Fonte: Elaboração própria com base em dados do Censo da Educação Básica.

Em 2017, na educação infantil, professores com nível médio representam aproximadamente $50 \%$ da quantidade de professores com nível superior. Essa proporção diminui de forma bastante evidente nas demais etapas. No ensino fundamental, a formação em nível médio é mais frequente nos anos iniciais (formação que é admitida nessa etapa) e se reduz nos anos finais (etapa em que essa escolaridade está em desacordo com a exigência legal). Esses dois indicadores, no entanto, têm apresentado tendência de queda ao longo do tempo, enquanto aumentam os percentuais de docentes com formação superior. No ensino médio, professores com nível superior são quase a totalidade, com participação bastante pequena de professores com nível médio.

Isso demonstra que, de forma geral, as redes de ensino vêm adaptando-se à exigência estabelecida pela legislação educacional (Brasil, 1996; 2014), admitida a exceção de nível médio, na modalidade normal, para docentes da educação infantil e dos anos iniciais do ensino fundamental.

Os Gráficos 7, 8, 9 e 10 evidenciam a distribuição de professores, para cada etapa, conforme escolaridade média ou superior, por região geográfica e tipo de localização da escola. 
Educação Infantil

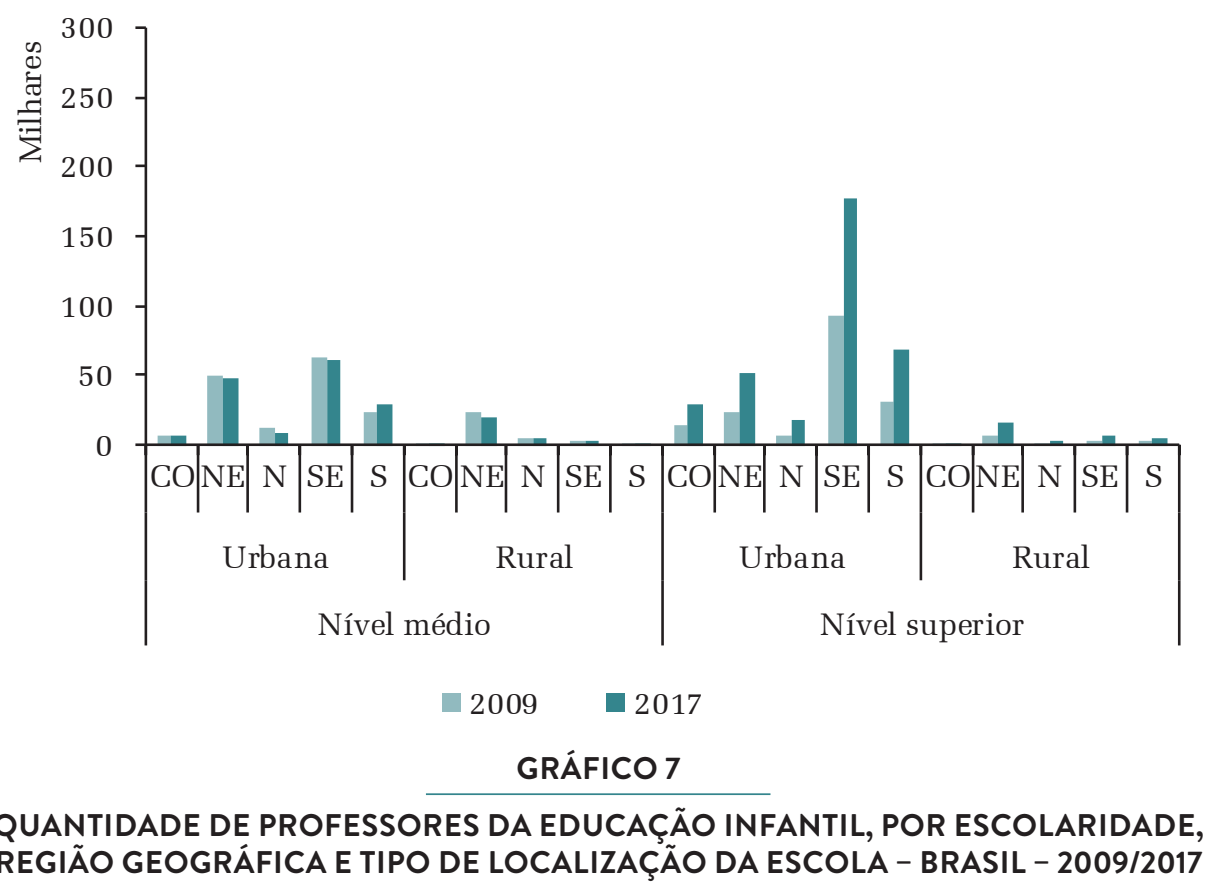

Fonte: Elaboração própria com base em dados do Censo da Educação Básica.

Anos Iniciais

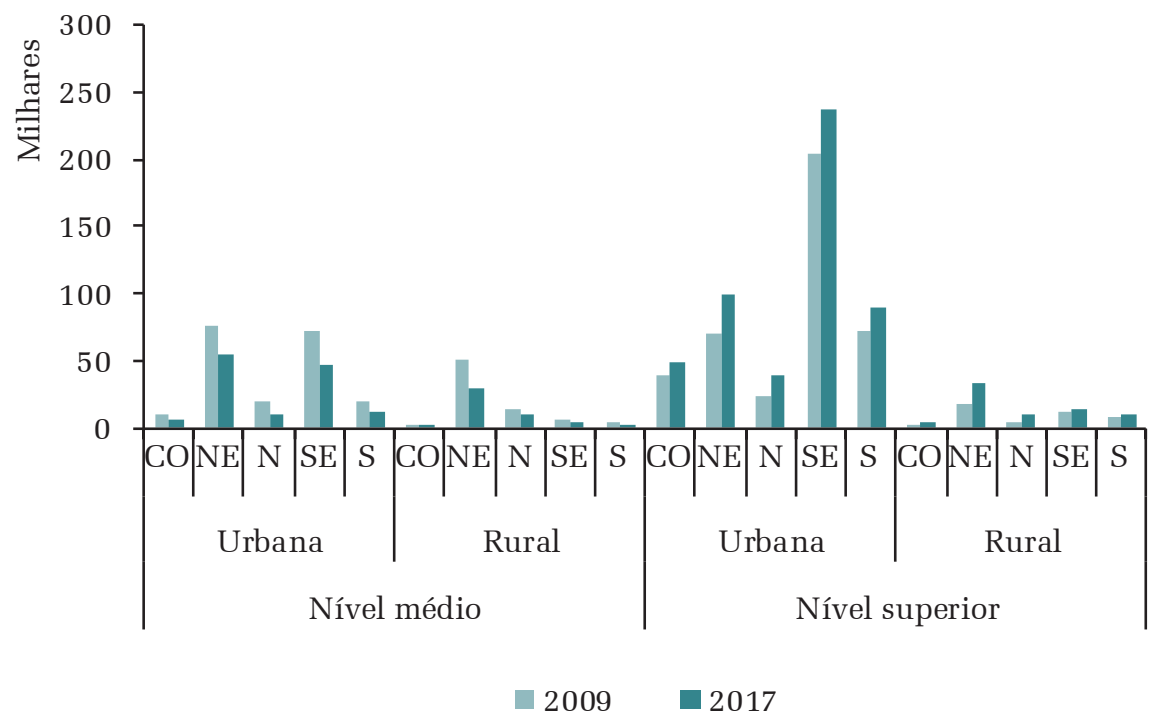

GRÁFICO 8

QUANTIDADE DE PROFESSORES DOS ANOS INICIAIS, POR ESCOLARIDADE, REGIÃO GEOGRÁFICA E TIPO DE LOCALIZAÇÃO DA ESCOLA - BRASIL - 2009/2017

Fonte: Elaboração própria com base em dados do Censo da Educação Básica. 
Anos Finais

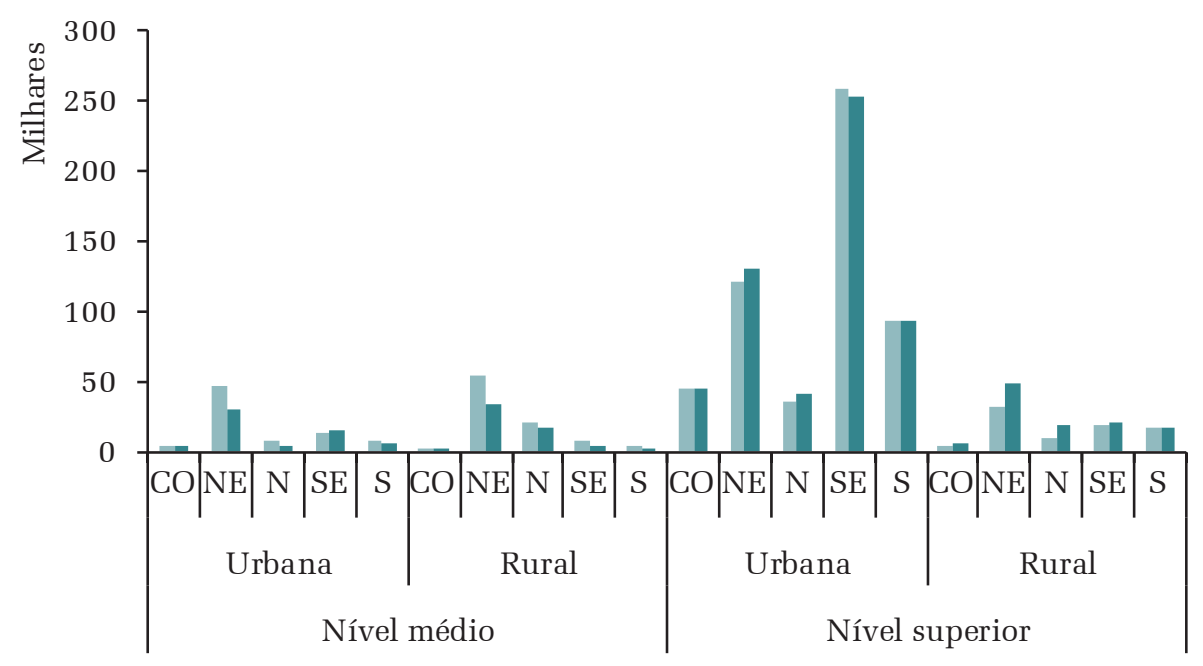

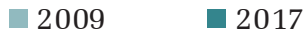

GRÁFICO 9

\section{QUANTIDADE DE PROFESSORES DOS ANOS FINAIS, POR ESCOLARIDADE, REGIÃO GEOGRÁFICA E TIPO DE LOCALIZAÇÃO DA ESCOLA - BRASIL - 2009/2017}

Fonte: Elaboração própria com base em dados do Censo da Educação Básica.

Ensino Médio

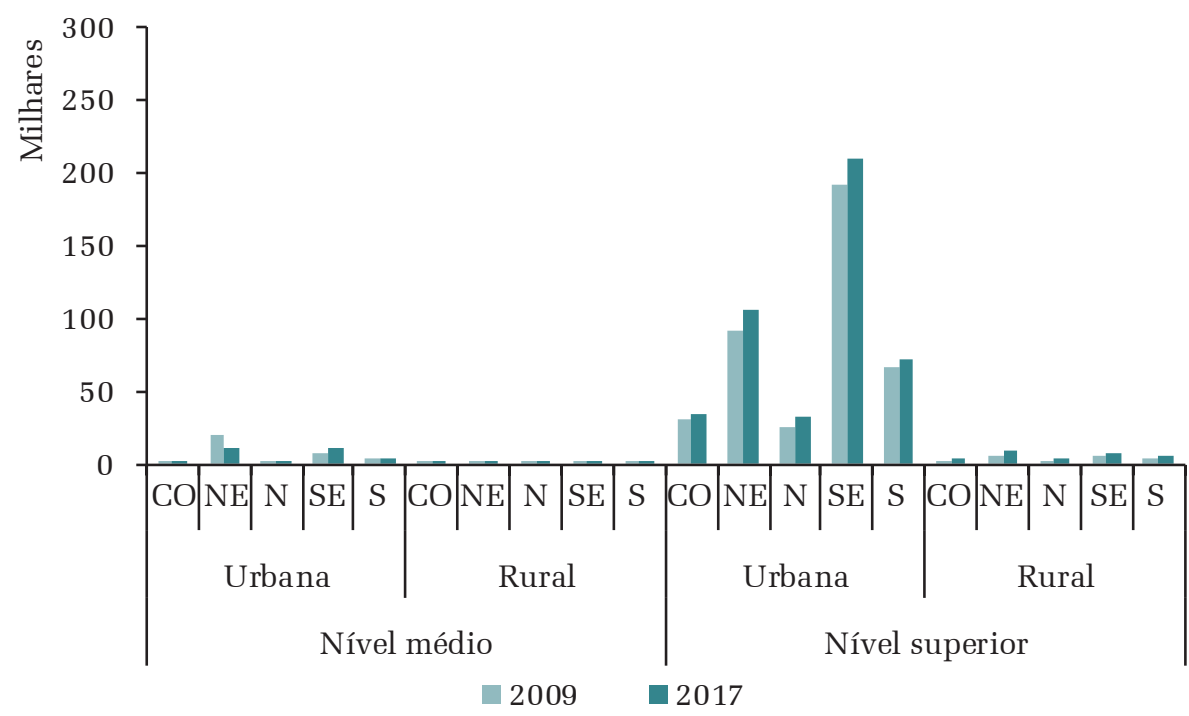

GRÁFICO 10

QUANTIDADE DE PROFESSORES DO ENSINO MÉDIO, POR ESCOLARIDADE, REGIÃO GEOGRÁFICA E TIPO DE LOCALIZAÇÃO DA ESCOLA - BRASIL - 2009/2017

Fonte: Elaboração própria com base em dados do Censo da Educação Básica. 
Pela análise desses gráficos, pode-se verificar que os professores com formação em nível superior concentram-se principalmente na região Sudeste e em localizações urbanas, em todas as etapas de ensino. Nas áreas rurais, existem maiores contingentes de professores com formação em nível médio, principalmente no Nordeste, na educação infantil e nos anos iniciais. No ensino médio, nas regiões rurais, quase não há docentes, comparativamente a regiões urbanas, com índices também bastante menores de professores com formação em nível superior. Esses dados refletem a dificuldade de alocação dos docentes em função da desigualdade socioeconômica que existe entre as regiões, ou seja, evidenciam a maior dificuldade de formação ou de retenção de professores com nível superior em localizações rurais e em regiões geográficas menos favorecidas.

O Gráfico 11 retrata a distribuição dos professores que possuem títulos de pós-graduação (lato ou stricto sensu), por etapas da educação e tipo de titulação.

Educação Infantil

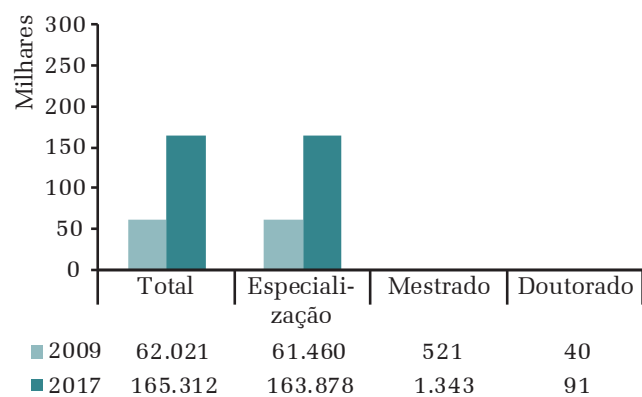

Anos Finais

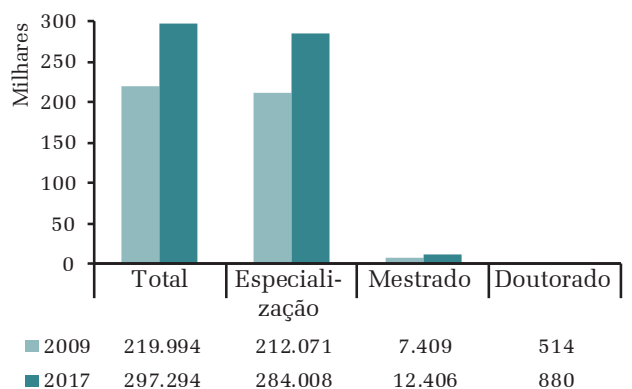

Anos Iniciais

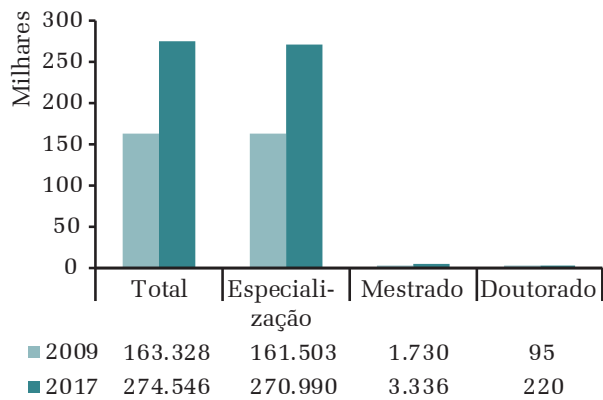

Ensino Médio

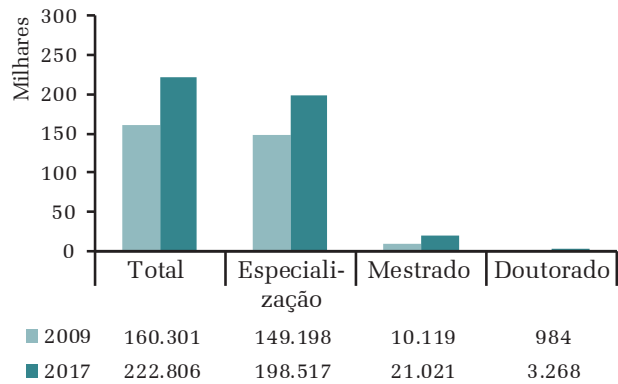

GRÁFICO 11

\section{QUANTIDADE DE PROFESSORES DA EDUCAÇÃO BÁSICA COM PÓS-GRADUAÇÃO, POR} ETAPA DE ENSINO E TIPO DE TITULAÇÃO - BRASIL - 2009/2017

Fonte: Elaboração própria com base em dados do Censo da Educação Básica. 
O percentual de professores com pós-graduação é menor na educação infantil do que nas demais etapas (17,2\% dos professores da educação infantil, 28,6\% dos anos iniciais, $31,0 \%$ dos anos finais e $23,2 \%$ do ensino médio), o que pode refletir o fato de que professores que adquirem essa titulação migram para etapas mais avançadas ou de que professores nessa etapa ainda não tiveram a oportunidade de obter essa titulação. Também na educação infantil se observa a menor quantidade de mestres e doutores, quando comparada às demais etapas (0,9\% dos títulos concedidos na educação infantil, 1,3\% nos anos iniciais, 4,5\% nos anos finais e 10,9\% no ensino médio). A quantidade de mestres e doutores cresce à medida que progridem as etapas de ensino e também ao longo do período, atingindo seu maior contingente no ensino médio. Em todas as etapas, no entanto, a titulação de especialização é a que predomina entre os pós-graduados.

A informação de tipo de vínculo profissional do professor não foi coletada no Censo da Educação Básica no ano de 2009. Somente os dados de 2017 serão, portanto, mencionados na Tabela 2.

TABELA 2

DISTRIBUIÇÃO DE PROFESSORES DA EDUCAÇÃO BÁSICA, POR ETAPAS DE ENSINO E TIPO DE VÍNCULO PROFISSIONAL - BRASIL - 2017

\begin{tabular}{|l|r|r|}
\hline \multicolumn{3}{|c|}{ Educação infantil } \\
\hline & N & \multicolumn{1}{|c|}{$\%$} \\
\hline Concursado & 292.672 & 51,6 \\
\hline Contrato CLT & 6.653 & 1,2 \\
\hline Temporário & 95.008 & 16,8 \\
\hline Terceirizado & 1.467 & 0,3 \\
\hline Privados & 171.158 & 30,2 \\
\hline Total & $\mathbf{5 6 6 . 9 5 8}$ \\
\hline
\end{tabular}

\begin{tabular}{|l|r|r|}
\hline \multicolumn{3}{|c|}{ Anos iniciais } \\
\hline Concursado & \multicolumn{1}{|c|}{ N } & \multicolumn{1}{c|}{$\%$} \\
\hline Contrato CLT & 433.973 & 55,4 \\
\hline Temporário & 6.322 & 0,8 \\
\hline Terceirizado & 156.087 & 19,9 \\
\hline Privados & 1.162 & 0,1 \\
\hline Total & 185.964 & 23,7 \\
\hline
\end{tabular}

\begin{tabular}{|l|r|r|}
\hline \multicolumn{3}{|c|}{ Anos finais } \\
\hline & \multicolumn{1}{|c|}{ N } & \multicolumn{1}{c|}{$\%$} \\
\hline Concursado & 444.073 & 54,9 \\
\hline Contrato CLT & 2.625 & 0,3 \\
\hline Temporário & 205.197 & 25,4 \\
\hline Terceirizado & 1.072 & 0,1 \\
\hline Privados & 155.396 & 19,2 \\
\hline Total & $\mathbf{8 0 8 . 3 6 3}$ \\
\hline
\end{tabular}

\begin{tabular}{|l|r|r|}
\hline \multicolumn{3}{|c|}{ Ensino médio } \\
\hline & N & \multicolumn{1}{c|}{$\%$} \\
\hline Concursado & 294.633 & 54,9 \\
\hline Contrato CLT & 1.686 & 0,3 \\
\hline Temporário & 137.104 & 25,5 \\
\hline Terceirizado & 526 & 0,1 \\
\hline Privados & 102.912 & 19,2 \\
\hline Total & $\mathbf{5 3 6 . 8 6 1}$ \\
\hline
\end{tabular}

Fonte: Elaboração própria com base em dados do Censo da Educação Básica. 
Quanto ao vínculo profissional, a maior parte dos professores da educação infantil na rede pública é concursada (52\%) ou temporária (17\%). Cerca de 30\% dos professores estão na rede particular, que tem uma participação importante nessa etapa. No ensino fundamental, aproximadamente $55 \%$ dos docentes são concursados na rede pública, cerca de 20 a 25\% são temporários e quase $20 \%$ são da rede privada. Também no ensino médio mais da metade dos professores são concursados (cerca de 55\%), 26\% são temporários e 19\% são vinculados à rede privada.

Os dados demonstram esforço no cumprimento da exigência de concurso para ingresso na carreira docente, mas indicam também que parte considerável dos professores ainda é contratada como temporária. Souza (2013) argumenta que professores concursados, em geral, têm condições salariais mais vantajosas. O aumento de profissionais estatutários pode, portanto, representar custos mais altos para o poder público, o que explica, de certa forma, a manutenção de um contingente de não concursados ao longo do tempo.

O contexto de trabalho do professor é analisado, também, em função da carga de trabalho a que ele está submetido, aferida, neste estudo, pela quantidade de escolas, turmas e disciplinas a que está vinculado. Entende-se que a maior quantidade de vínculos do professor afeta a possibilidade de seu envolvimento mais efetivo com o trabalho, impactando a qualidade do ensino.

Os Gráficos 12, 13, 14 e 15 trazem esses dados para cada etapa de ensino. A informação de disciplinas é apresentada apenas para os anos finais e o ensino médio - etapas em que o ensino é disciplinar.

\section{Educação infantil}

Escolas por professor

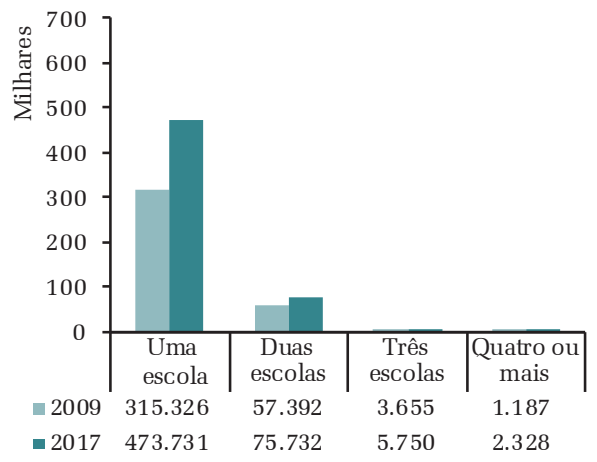

Turmas por professor

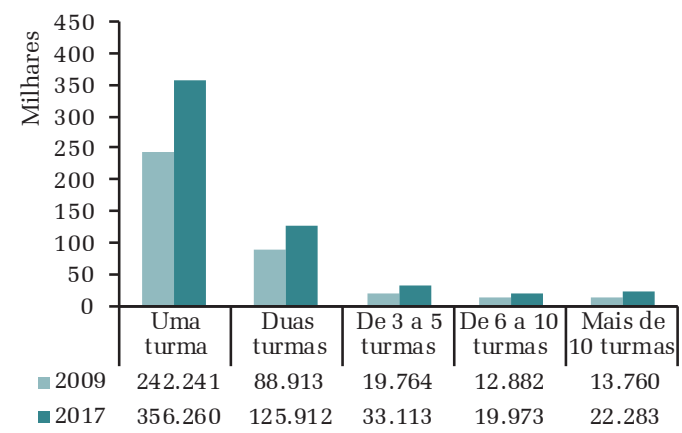

GRÁFICO 12

\section{QUANTIDADE DE PROFESSORES DA EDUCAÇÃO INFANTIL, POR NÚMERO DE ESCOLAS E} TURMAS A QUE SE VINCULAM - BRASIL - 2009/2017

Fonte: Elaboração própria com base em dados do Censo da Educação Básica. 
Analisando-se os dados do Gráfico 12, observa-se que, em 2017, grande parte dos professores da educação infantil trabalha em uma (85\%) ou duas escolas (14\%) e leciona em uma (64\%) ou duas turmas (23\%). Isso reflete o fato de que o professor, nessa etapa de ensino, é dedicado a uma turma, de forma multidisciplinar, durante todo o período letivo, trabalhando em menos turmas e em menos escolas.

\section{Anos iniciais}
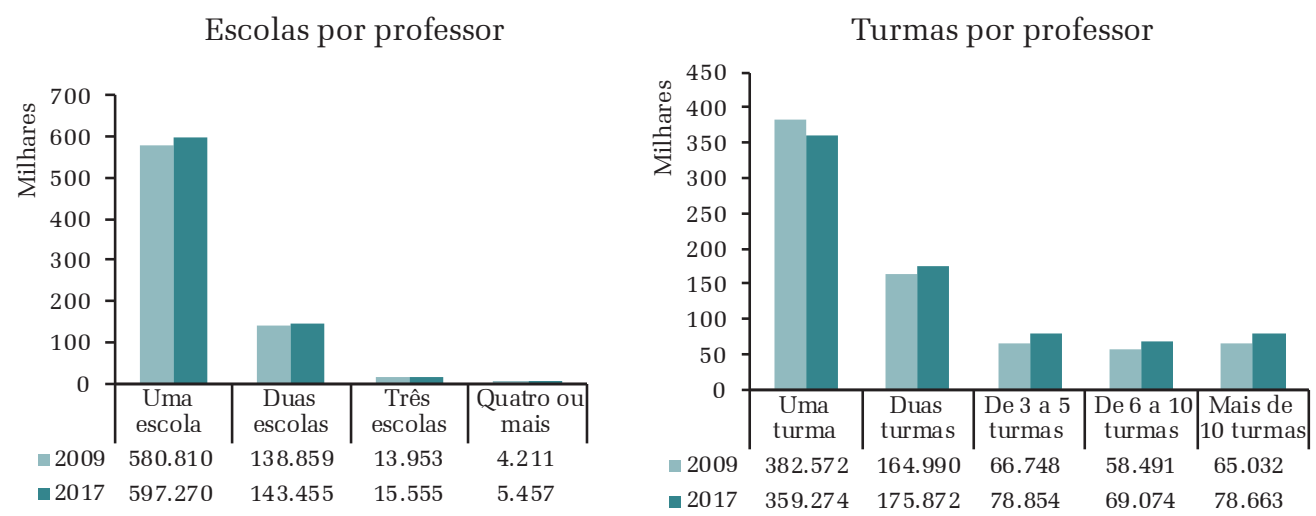

GRÁFICO 13

\section{QUANTIDADE DE PROFESSORES DOS ANOS INICIAIS, POR NÚMERO DE ESCOLAS E TURMAS A QUE SE VINCULAM - BRASIL - 2009/2017}

Fonte: Elaboração própria com base em dados do Censo da Educação Básica.

No ensino fundamental (anos iniciais, Gráfico 13, e anos finais, Gráfico 14), constata-se que a maior parte dos professores trabalha em apenas uma escola e, em menor proporção, em duas escolas. Professores dos anos finais apresentaram índices mais altos de vínculos em maior quantidade de turmas, quando comparados aos dos anos iniciais - sendo frequentes os casos de professores vinculados a mais de seis turmas, por exemplo. Isso ocorre, provavelmente, porque os anos finais são divididos em disciplinas e os anos iniciais são ministrados por um professor multidisciplinar, ou seja, o professor nos anos finais leciona uma mesma disciplina em diferentes turmas, apresentando, portanto, vínculos com maior quantidade de turmas ou escolas. 


\section{Anos finais}
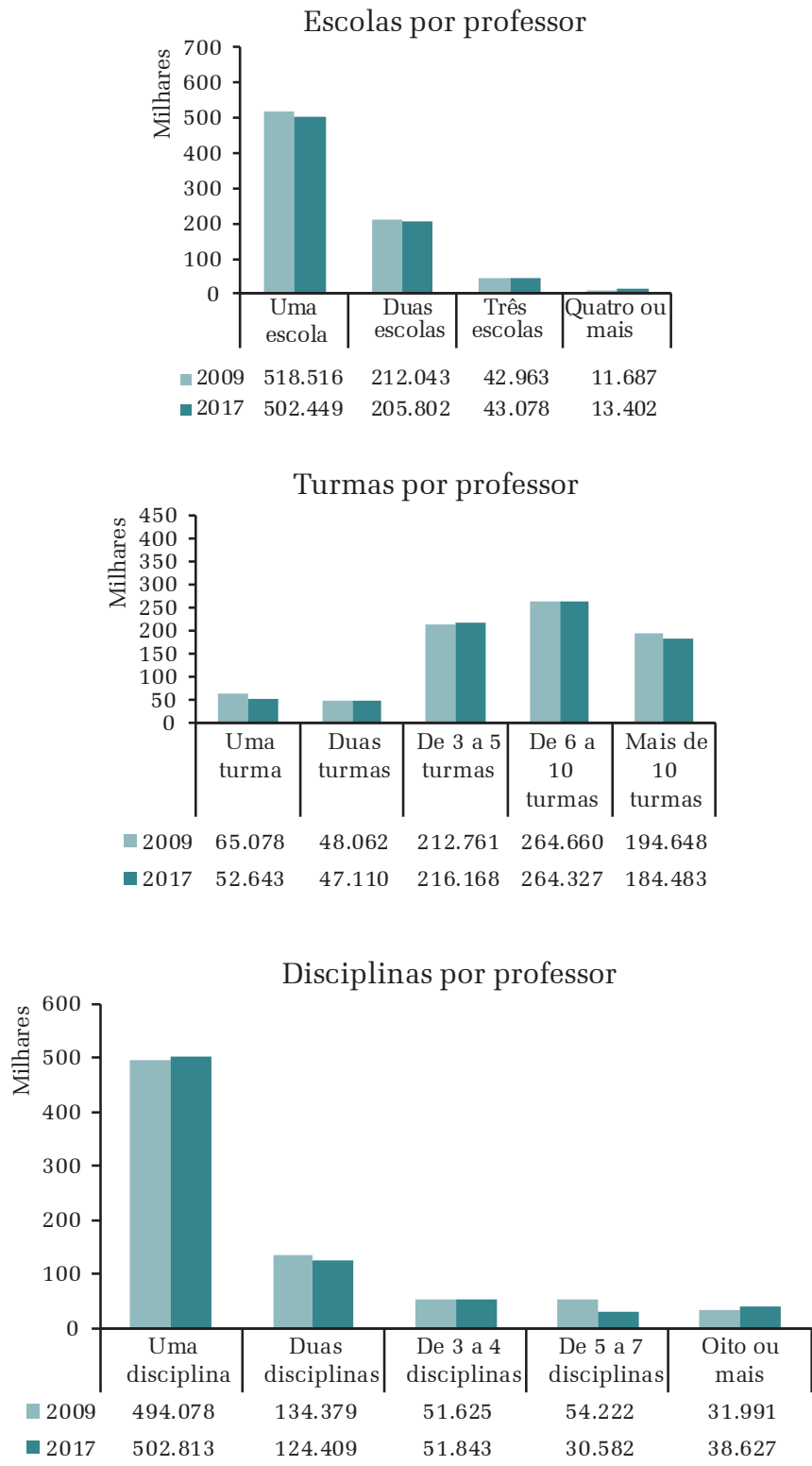

GRÁFICO 14

\section{QUANTIDADE DE PROFESSORES DOS ANOS FINAIS, POR NÚMERO DE ESCOLAS, TURMAS E DISCIPLINAS A QUE SE VINCULAM - BRASIL - 2009/2017}

\section{Fonte: Elaboração própria com base em dados do Censo da Educação Básica.}

Para os anos finais, em que existe a previsão de ensino por disciplinas, o Gráfico 14 revela que a maioria dos professores está alocada em uma (64\%) ou duas (16\%) disciplinas, que podem ser ministradas em várias turmas. 
Ensino médio
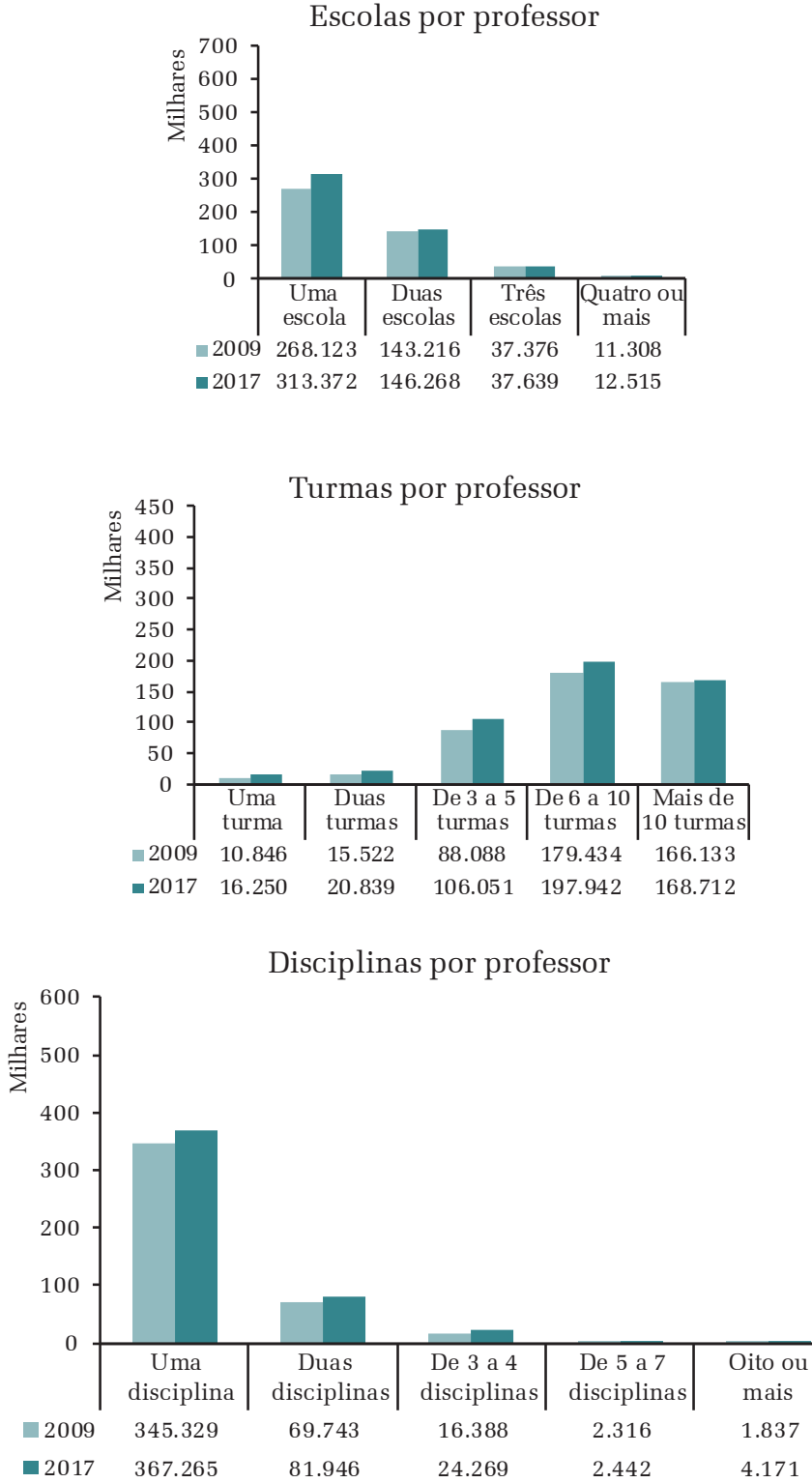

GRÁFICO 15

QUANTIDADE DE PROFESSORES DO ENSINO MÉDIO, POR NÚMERO DE ESCOLAS, TURMAS E DISCIPLINAS A QUE SE VINCULAM - BRASIL - 2009/2017

Fonte: Elaboração própria com base em dados do Censo da Educação Básica.

Os professores no ensino médio (Gráfico 15) possuem, em comparação com os das demais etapas, maior quantidade de vínculos em mais de uma escola e com várias turmas (são frequentes os casos de vínculos com seis ou mais turmas), provavelmente porque lecionam por disciplinas. 
A análise da carga de trabalho dos professores é importante quando se considera o impacto que isso representa em termos de esforço e desgaste. Estudos mostram que os docentes declaram, como parte dos problemas que enfrentam, em relação à profissão: i) o vínculo com muitas turmas, superlotadas; ii) o mau comportamento dos alunos, sem que tenham disponibilidade suficiente para dedicar a atenção necessária; iii) o fato de não se sentirem preparados, em termos de formação adequada à disciplina que ministram; iv) os baixos salários, que os estimulam a terem outros empregos, implicando menos tempo disponível para o ensino, em função da dedicação não exclusiva (Unesco, 2004; Oliveira; Alves, 2005; Gatti; Barretto, 2009; Scheibe, 2010).

\section{CONSIDERAÇÕES FINAIS}

A compreensão do perfil do professor e das peculiaridades de suas características conforme a etapa de ensino é importante para conhecer, em maiores detalhes, quem é esse profissional e qual o contexto em que trabalha e para se apreender o papel que desempenha no processo escolar, no evento de ensino-aprendizagem e nos resultados escolares dos estudantes (Scorzafave, 2011). São os professores, em última instância, que efetivam na prática, na sala de aula, as ações concebidas pelas políticas educacionais (Souza; Gouveia, 2011).

O estudo revelou que o número de professores da educação infantil é o que apresentou maior taxa de crescimento ao longo do período analisado, e estes estão distribuídos prioritariamente entre as regiões Sudeste e Nordeste, em escolas municipais. O profissional típico dessa etapa é do sexo feminino, de cor/raça branca (ainda que a presença de professores pretos e pardos esteja aumentando), com média etária de 39 anos e nível de formação superior, embora existam também alguns professores com nível médio. Concursados representam mais da metade dos docentes dessa etapa. A maioria trabalha em uma escola e com apenas uma turma.

O número de professores do ensino fundamental não apresentou tendência evidente de crescimento ao longo do período, com números relativamente estáveis entre 2009 e 2017, distribuídos principalmente nas regiões Sudeste e Nordeste, em quantidades bastante semelhantes entre anos iniciais e anos finais. Estão alocados principalmente em escolas municipais, com participação maior nas escolas estaduais para os anos finais. A maioria dos professores dessa etapa é composta por mulheres e brancas, com idade média de 41 anos e formação em nível de graduação, embora nos anos iniciais seja possível se observar um contingente maior de professores com nível médio se comparado ao dos anos finais. A maior parte dos professores é concursada e trabalha em apenas uma escola. Nos anos finais, nota-se que os professores estão vinculados a mais turmas do que nos anos iniciais, mas lecionam, em sua maioria, somente uma disciplina. 
A quantidade de professores do ensino médio apresentou ligeira tendência de crescimento ao longo do tempo, estando estes mais presentes nas regiões Sudeste e Nordeste e, na sua maioria, em escolas estaduais. Embora ainda em menor proporção do que as mulheres, é nessa etapa que estão alocados mais professores do sexo masculino. Predominam, no ensino médio, professoras brancas, na faixa etária média de 42 anos, prioritariamente com nível de formação superior e concursadas. Nessa etapa, os professores estão vinculados, em geral, a até duas escolas, mas em uma quantidade maior de turmas, lecionando uma disciplina em média.

Por fim, é importante lembrar que o professor não é o único elemento em que se deve investir com o objetivo de se obter qualidade de ensino e aprendizado do aluno e que outros fatores também devem fazer parte do delineamento de políticas de apoio ao docente, como "[...] a valorização social da profissão, os salários, as condições de trabalho, a infraestrutura das escolas, as formas de organização do trabalho escolar, a carreira” (Gatti; Barreto; André, 2011, p. 15; André, 2013). É esse conjunto de políticas de valorização da carreira de professor que vai influenciar na atração de novos profissionais e na permanência de bons professores na docência - bem formados, dedicados à profissão e motivados no preparo de seus alunos.

\section{REFERÊNCIAS}

ANDRÉ, M. Políticas de apoio aos docentes em estados e municípios brasileiros: dilemas na formação de professores. Educar em Revista, Curitiba, n. 50, p. 35-49, out./dez. 2013.

BRASIL. Constituição (1988). Constituição da República Federativa do Brasil. Brasília, 1988.

BRASIL. Decreto n ${ }^{0} 3.276$, de 6 de dezembro de 1999. Dispõe sobre a formação em nível superior de professores para atuar na educação básica, e dá outras providências. Diário Oficial da União, Brasília, DF, 7 dez. 1999. Seção 1, p. 4.

BRASIL. Lei $\mathrm{n}^{0}$ 9.394, de 20 de dezembro de 1996. Estabelece as diretrizes e bases da educação nacional. Diário Oficial da União, Brasília, DF, 23 dez. 1996. Seção 1, p. 27833.

BRASIL. Lei $\mathrm{n}^{\circ}$ 13.005, de 25 de junho de 2014. Aprova o Plano Nacional de Educação - PNE e dá outras providências. Diário Oficial da União, Brasília, DF, 26 jun. 2014. Seção 1, p. 1. 
BRASIL. Conselho Nacional de Educação (CNE). Parecer CNE/CEB n ${ }^{\circ}$ 2, de 30 de janeiro de 2008. Solicitação de Parecer sobre formação e atuação de docentes na organização pedagógica do Ensino Fundamental, considerando a lógica dos ciclos de formação humana. Brasília, 2008. Disponível em: < http://portal.mec.gov.br/cne/ arquivos/pdf/2008/pceb002_08.pdf>. Acesso em: 26 mar. 2018.

BRASIL. Ministério da Educação (MEC). Base Nacional Comum Curricular: educação é a base. Brasília, 2017. Disponível em: < http://basenacionalcomum.mec.gov.br/ wp-content/uploads/2018/02/bncc-20dez-site.pdf> . Acesso em: 26 mar. 2018.

BRASIL. Instituto Nacional de Estudos e Pesquisas Educacionais (Inep). Sinopse estatística da educação básica 2009. Brasília, 2010. Disponível em: <http://portal. inep.gov.br/sinopses-estatisticas-da-educacao-basica >. Acesso em: 28 mar. 2018.

BRASIL. Instituto Nacional de Estudos e Pesquisas Educacionais (Inep). Sinopse estatística da educação básica 2017. Brasília, 2018. Disponível em: <http://portal. inep.gov.br/sinopses-estatisticas-da-educacao-basica > . Acesso em: 28 mar. 2018.

CARVALHO, M. R. V. Perfil do professor da educação básica. Brasília: Inep, 2018. (Série Documental. Relatos de Pesquisa, 41).

CURY, C. R. J. A educação básica como direito. Cadernos de Pesquisa, São Paulo, v. 38, n. 134, p. 293-303, maio/ago. 2008.

CURY, C. R. J. A educação básica no Brasil. Educação e Sociedade, Campinas, v. 23, n. 80 , p. $168-200$, set. 2002.

GATTI, B. A.; BARRETTO, E. S. S. (Coord.) Professores do Brasil: impasses e desafios. Brasília: Unesco, 2009.

GATTI, B. A.; BARRETTO, E. S. S.; ANDRÉ, M. E. D. A. Escopo do trabalho, abrangência e abordagem. In: GATTI, B. A.; BARRETO, E. S. S.; ANDRÉ, M. E. D. A. Políticas docentes no Brasil: um estado da arte. Brasília: Unesco, 2011. p. 13-20.

MENDES, M. S. Da inclusão à evasão escolar: o papel da motivação no ensino médio. Estudos de Psicologia, Campinas, v. 30, n. 2, p. 261-265, abr./jun. 2013.

OLIVEIRA, C. B. E.; ALVES, P. B. Ensino fundamental: papel do professor, motivação e estimulação no contexto escolar. Paidéia, Ribeirão Preto, v. 15, n. 31, p. 227-238, maio/ago. 2005. 
ORGANIZAÇÃO DAS NAÇÕES UNIDAS PARA A EDUCAÇÃO, A CIÊNCIA E A CULTURA (Unesco). O perfil dos professores brasileiros: o que fazem, o que pensam, o que almejam. São Paulo: Moderna, 2004.

SCHEIBE, L. Valorização e formação dos professores para a educação básica: questões desafiadoras para um novo plano nacional de educação. Educação e Sociedade, Campinas, v. 31, n. 112, p. 981-1000, jul./set. 2010.

SCORZAFAVE, L. G. D. S. Características do professor brasileiro do ensino fundamental: diferenças entre o setor público e o privado. Economia \& Tecnologia, Curitiba, v. 7, n. 2, p. 1-8, abr./jun. 2011.

SOUZA, A. R. O professor da educação básica no Brasil: identidade e trabalho. Educar em Revista, Curitiba, n. 48, p. 53-74, abr./jun. 2013.

SOUZA, A. R.; GOUVEIA, A. B. Os trabalhadores docentes da educação básica no Brasil em uma leitura possível das políticas educacionais. Arquivos Analíticos de Políticas Educativas, Tempe, v. 19, n. 35, p. 1-22, dez. 2011.

VIANNA, C. P. O sexo e o gênero da docência. Cadernos Pagu, Campinas, n. 17-18, p. 81-103, 2001. 
